Riwayat draf artikel Diserahkan 19-11-2021 Direvisi 19-12-2021 Diterima 25-12-2021 Publish 27-12-2021

\section{Efektivitas Komik Digital Sebagai Media Pembelajaran Daring pada Materi Sistem Persamaan Linear Dua Variabel}

Davi Maya Maghrobi Arum¹, Wahyuni Suryaningtyas ${ }^{2}$, Sandha Soemantri ${ }^{3}$

Program Studi Pendidikan Matematika, Universitas Muhammadiyah Surabaya ${ }^{1,2,3}$

Email: davimaya81@gmail.com ${ }^{1}$,wahyuni.pendmat@fkip.umsurabaya.ac.id ${ }^{2}$, sandha.pendmat@fkip.um-surabaya.ac.id ${ }^{3}$

\begin{abstract}
ABSTRAK: Tujuan dari penelitian ini adalah mendeskripsikan keterlaksanaan pengelolaan pembelajaran yang dilakukan guru, aktivitas selama pembelajaran, hasil belajar, dan respon siswa setelah mengikuti pembelajaran menggunakan Komik Digital sebagai media pembelajaran daring pada materi SPLDV. Penelitian ini adalah penelitian deskriptif kuantitatif dengan desain One-Shot Case Study. Partisipan penelitian sebanyak 31 siswa SMP Muhammadiyah 13 Surabaya. Hasil penelitian menunjukkan bahwa; Pertama, efektivitas guru dalam mengelola pembelajaran termasuk kategori sangat baik dengan rata-rata 95\%. Kedua, efektivitas aktivitas siswa selama mengikuti pembelajaran termasuk kategori sangat aktif dengan rata-rata 3,70. Ketiga, efektivitas ketuntasan hasil belajar siswa dikatakan tuntas dengan persentase ketuntasan klasikal 97\%, dan keempat, efektivitas respon siswa termasuk dalam kategori sangat positif. Dengan demikian, peneliti menyimpulkan bahwa penggunaan Komik Digital sebagai media pembelajaran daring efektif terhadap hasil belajar matematika siswa pada materi SPLDV di SMP Muhammadiyah 13 Surabaya.
\end{abstract}

Katakunci: Komik Digital, Matematika, Media Pembelajaran.

ABSTRACT: The purpose of this study are to describe the teacher's implementation of managing learning, student activities during learning, student learning outcomes, student responses after participating in learning using Digital Comics as an online learning medium on SPLDV material. The method used is quantitative descriptive research with a One-Shot Case Study design. Subject the research consisted of 31 students of SMP Muhammadiyah 13 Surabaya. The results show that (1) the effectiveness of teachers in managing to learn is in the very good category with an average of $95 \%$, (2) the effectiveness of student activities during learning is included in the very active category with an average of 3.70, (3) the effectiveness of completeness results student learning is said to be complete with a classical completeness percentage of $97 \%$, (4) the effectiveness of student responses is included in the very positive category. From the result above, it can be concluded that the use of Digital Comics as an online learning media is effective for students learning mathematics outcomes in SPLDV subjects at SMP Muhammadiyah 13 Surabaya.

Keywords: Digital Comics, Mathematics, Learning Media.

\title{
PENDAHULUAN
}

Matematika merupakan salah satu ilmu pengetahuan yang sangat penting dalam kehidupan sehari-hari. Matematika menurut Kline (Rahmah, 2013) merupakan pengetahuan yang tidak menyendiri dimana dapat sempurna karena 
dirinya sendiri, tetapi dengan adanya matematika yaitu untuk membantu manusia dalam mengatasi permasalahan ekonomi, sosial dan alam. Matematika dapat tumbuh dan berkembang karena adanya proses berpikir, oleh karena itu logika adalah dasar untuk terbentuknya suatu matematika.

Metematika memiliki kegunaan untuk menunjang aktivitas manusia. Oleh karena itu pelajaran matematika merupakan salah satu pelajaran yang sangat penting untuk diajarkan kepada siswa. Namun, banyak siswa di Indonesia menilai mata pelajaran matematika cukup sulit dipahami. Ini terbukti dari hasil penelitian yang dilakukan oleh salah satu mahasiswa program doktor psikologi Universitas Gadjah Mada yakni Nani Restati Siregar. Hasil penelitian menemukan bahwa 20\% siswa mengatakan matematika sangat sulit, $35 \%$ siswa mengatakan matematika mudah dan menyenangkan, dan $45 \%$ siswa mengatakan matematika cukup sulit sehingga sikap positif dari guru terhadap pembelajaran matematika berpengaruh pada terbentuknya sikap positif siswa pada pembelajaran matematika (Siregar, 2017). Dalam hal ini, guru merupakan faktor penting untuk dapat menentukan berhasil atau tidaknya siswa dalam belajar sesuai dengan UU No. 14 tahun 2005 (Kemenkeu, 2005). Pentingnya peran guru tidak terlepas dari kemampuan guru dalam memilih model pembelajaran dan media yang tepat di era revolusi industri 4.0 yaitu media pembelajaran berbasis teknologi agar dapat menarik minat belajar siswa seperti Komik Digital. Sedangkan salah satu model pembelajaran yang dapat digunakan dalam pembelajaran matematika yaitu model pembelajaran problem based learning (PBL), hal ini terbukti dalam penelitian sebelumnya oleh Lia Andesta dengan judul "Pengaruh Model Pembelajaran Problem Based Learning (PBL) Terhadap Hasil Belajar Matematika Peserta Didik di Kelas IV MIN 11 Bandar Lampung" hasil penelitian menunjukkan bahwa terdapat pengaruh model pembelajaran PBL terhadap hasil belajar matematika peserta didik kelas IV MIN 11 Bandar Lampung. Menurut Duch (Astraman et al., 2017) model pembelajaran PBL adalah model pembelajaran yang menghadapkan siswa pada permasalahan dunia nyata yang bermakna bagi siswa.

Pembelajaran matematika menggunakan komik dengan model PBL adalah pembelajaran yang dirancang oleh guru bertujuan untuk menciptakan suasana lingkungan yang memungkinkan terjadinya aktivitas belajar matematika. Dalam penelitian sebelumnya yang relevan dari (Permana sidik, 2013) dengan judul "Efektivitas Media Komik Digital terhadap Peningkatan Hasil Belajar Siswa Pada Mata Pelajaran Sejarah". Hasil penelitian menunjukkan bahwa penggunaan media pembelajaran komik dapat meningkatkan hasil belajar ranah kognitif aspek sintesis siswa pada pembelajaran sejarah dan juga penelitian sebelumnya dari (Kurniati et al., 2017) dengan judul "Efektivitas Media Komik Pada Materi Sifat-Sifat Bangun Ruang Untuk Siswa Kelas V SD Negeri 61 Kota Bengkulu". Hasil penelitian tersebut menunjukkan bahwa media komik yang dikembangkan dikategorikan efektif dalam pembelajaran matematika pada meteri sifat-sifat bangun ruang.

Studi awal yang dilakukan pada tanggal 20 Desember 2020 bahwa pada saat pembelajaran berlangsung di era pandemi ini guru membagi kegiatan belajar mengajar menjadi dua yaitu luar jaringan (luring) dan dalam jaringan 
(daring). Dalam kegiatan luring guru memberi tugas portofolio kepada siswa, sedangkan secara daring guru memberi penjelasan materi yang sudah ada melalui youtube, selanjutnya memberikan tugas melalui google classroom. Namun kurang ada feedback dari tugas yang diberikan tersebut. Dalam hal ini media yang digunakan kurang menarik perhatian dan metode yang digunakan masih menggunakan metode konvensional yang mengakibatkan siswa menjadi jenuh sehingga kurangnya minat dalam belajar matematika dan akan terhambat dalam menerima pembelajaran, yang mengakibatkan hasil belajar siswa kurang baik sehingga tingkat keberhasilan siswa tidak merata.

Pembelajaran menggunakan komik dengan model PBL adalah pembelajaran yang dirancang oleh guru bertujuan menciptakan suasana lingkungan yang memungkinkan terjadinya aktivitas belajar matematika sehingga memberikan peluang siswa untuk berusaha mencari pengalamannya sendiri yang dihadapkan dengan permasalahan dunia nyata yang mana komik ini dapat mendorong keterlibatan siswa dan dapat meningkatkan aktivitas siswa. Pemahaman berkembang semakin dalam dan kuat apabila selalu diberi berbagai macam latihan pengalaman baru, belajar matematika melalui Komik dengan model pembelajaran PBL menjadi lebih bermakna sehingga hasil belajar siswa dapat meningkat.

Tujuan penelitian ini adalah adalah mendeskripsikan keterlaksanaan mengelola pembelajaran oleh guru, aktivitas siswa selama pembelajaran, hasil belajar siswa, respon siswa setelah mengikuti pembelajaran menggunakan Komik Digital sebagai media pembelajaran daring pada materi.

\section{METODE PENELITIAN}

Menurut masalah yang ditemukan dan upaya untuk memecahkan masalah tersebut maka peneliti menggunakan jenis penelitian deskriptif kuantitatif dengan desain One-Shot Case Study yaitu satu kelas dikenakan treatmen/perlakuan yang selanjutnya diobservasi hasilnya (Sugiyono,2013). Penelitian deskriptif kuantitatif adalah metode penelitian yang dimaksudkan untuk menyelidiki keadaan kondisi, situasi yang hasilnya dipaparkan dengan proses analisis menggunakan rumus statistik untuk diambil hasil akhir.

Penelitian dilaksanakan pada awal semester genap tahun pelajaran 2020/2021 di kelas VIII SMP Muhammadiyah 13 Surabaya yang beralamat di J. Tambak Segaran No.27, Kapas Krampung, Surabaya dengan tujuan mendeskripsikan peran guru menggunakan Komik Digital, aktivitas siswa, hasil belajar siswa, dan respon siswa.

Subjek dalam penelitian ini adalah siswa kelas VIII-A dan VIII-B SMP Muhammadiyah 13 Surabaya sebagai populasi dan sebanyak 31 siswa kelas VIII-B sebagai sampel. Pengambilan sampel dilakukan dengan Teknik pengambilan acak sederhana (Simple Random Sampling) karena tidak ada perbedaan karakter dari kedua kelas tersebut. Sebelum pengambilan sampel Penelitian, dilakukan terlebih dahulu uji homogentitas terhadap kelas VIII-A dan VIII-B dengan menggunakan Uji-F. Setelah dilakukan pengujian homogenitas ternyata kedua kelas homogen. 
Teknik pengumpulan data menggunakan metode tes untuk mengetahui ketuntasan hasil belajar siswa, observasi untuk mengamati kegiatan guru dan siswa, kuesioner untuk mengetahui respon siswa terhadap pembelajaran menggunakan media Komik Digital dengan instrumen lembar tes, observasi dan angket. Angket yang digunakan yaitu angket tertutup, menurut Arikunto (Laksana, 2019) angket tertutup merupakan angket yang disajikan atas pertanyaan atau pernyataan yang sudah dikemas sehingga responden tinggal memberi tanda checklist $(\checkmark)$ Prosedur penelitian ini memiliki tiga tahap dalam pembelajaran antara lain, tahap persiapan, tahap pelaksanaan, dan tahap pengolahan data. Berikut penjelasan tahap-tahap tersebut:

\section{Tahap Persiapan}

Mengajukan permohonan izin penelitian, melakukan survei awal untuk mencari gambaran umum tentang objek penelitian, melakukan kesepakatan dengan guru mata pelajaran matematika tentang waktu penelitian dan materi yang akan diteliti, menyusun RPP, dan terakhir yaitu menyusun instrument.

\section{Tahap Pelaksanaan}

Sebelum pelaksanaan pembelajaran, instrumen beserta media divaliasi terlebih dahulu kepada beberapa ahli Pendidikan. Berikutnya dilakukan tahap pelaksanaan antara lain: melaksanaan kegiatan pembelajaran secara daring yaitu penerapan model PBL menggunakan media Komik Digital pada materi SPLDV, kemudian memberikan soal tes pada akhir pertemuan pembelajaran untuk mengetahui ketuntasan hasil belajar siswa dalam menguasai materi, dan memberikan angket respon siswa untuk mengetahui respon siswa terhadap penggunaan komik digital.

\section{Tahap Analisis Data}

Dalam tahap mengelola dan menganalisis data yang diperoleh dari hasil penelitian yaitu data deskriptif kuantitatif. Data kuantitatif diperoleh dari hasil tes siswa, untuk mengetahui kemampuan siswa dalam menyelesaikan masalah pada pembelajaran matematika menggunakan Komik Digital sebagai media pembelajaran daring pada materi SPLDV. Sedangkan data deskriptif didapat dari hasil lembar observasi untuk mengetahui keterlaksanaan guru dalam mengelola pembelajaran, serta aktivitas siswa dalam menggunakan media, dan lembar angket untuk mengetahui respon siswa.

a. Analisis Data Keterlaksanaan Guru dalam Mengelola Pembelajaran

Menghitung serta menginterpretasikan nilai rata-rata skor keseluruhan keterlaksanaan guru dalam mengelola pembelajaran daring menggunakan rumus yang diadaptasi dari Marsigit dan Roh (2015) dengan indikator tercapainya efektivitas guru mengelola pembelajaran dapat dilihat pada Tabel 1.

Tabel 1. Kategori Penilaian Keterlaksanaan Guru

\begin{tabular}{|c|l|}
\hline Rata-rata Skor Total & \multicolumn{1}{c|}{ Kategori } \\
\hline $\boldsymbol{P}<\mathbf{5 0} \%$ & Tidak Baik \\
\hline $\mathbf{5 0} \%<\boldsymbol{P} \leq \mathbf{7 0} \%$ & Kurang Baik \\
\hline
\end{tabular}




\begin{tabular}{|c|l|}
\hline $\mathbf{7 0} \%<\boldsymbol{P} \leq \mathbf{8 5} \%$ & Baik \\
\hline $\mathbf{8 5} \%<\boldsymbol{P}$ & Sangat Baik \\
\hline
\end{tabular}

Apabila rata-rata keseluruhan yang diamati mencapai kategori baik atau sangat baik maka RPP dapat dikatakan praktis, begitu sebaliknya.

b. Analisis Data Aktivitas Siswa

Menghitung serta menginterpretasikan nilai rata-rata skor total aktivitas siswa menggunakan rumus yang diadaptasi dari Affidah (2017) dengan Indikator tercapainya efektivitas aktivitas siswa dapat dilihat pada Tabel 2.

Tabel 2. Kategori Penilaian Aktivitas Siswa

\begin{tabular}{|c|c|}
\hline Rata-rata Skor Total & Kategori \\
\hline $1,00 \leq S A S<2,00$ & Tidak Aktif \\
\hline $2,00 \leq S A S<3,00$ & Kurang Aktif \\
\hline $3,00 \leq S A S<3,50$ & Aktif \\
\hline $3,50 \leq S A S<4,00$ & Sangat Aktif \\
\hline
\end{tabular}

Kriteria aktivitas siswa dikatakan baik jika aktivitas siswa pada saat proses pembelajaran berlangsung dalam kategori aktif atau sangat aktif.

c. Analisis Data Tes Kemampuan Siswa

Untuk mengetahui ketuntasan hasil belajar siswa baik secara individu maupun klasikal menggunakan rumus yang diadaptasi dari Laela (2013) dengan Indikator tercapainya efektivitas hasil belajar siswa didasarkan pada standar ketuntasan SMP Muhammadiyah 13 Surabaya yaitu siswa dikatakan tuntas belajar jika mendapat nilai minimal 75 secara individu dan suatu kelas dapat dikatakan tuntas belajar secara klasikal tercapai minimal $75 \%$ dari siswa yang telah mencapai ketuntasan secara individu.

d. Analisis Data Angket Siswa

Menghitung nilai respon siswa beserta persentase respon siswa menggunakan rumus yang diadaptasi dari Sudjana (dalam Affidah,2017) dengan Indikator tercapainya efektivitas respon siswa dapat dilihat pada Tabel 3.

Tabel 3. Kriteria Penilaian Respon Siswa

\begin{tabular}{|c|c|}
\hline Nilai Respon Siswa & Kriteria \\
\hline $0 \% \leq N R S<25 \%$ & Tidak Positif \\
\hline $25 \% \leq N R S<50 \%$ & Kurang Positif \\
\hline $50 \% \leq N R S<75 \%$ & Positif \\
\hline $75 \% \leq N R S<100 \%$ & Sangat Positif \\
\hline
\end{tabular}

Apabila $\geq 75 \%$ dari seluruh butir pernyataan yang dikategorikan positif atau sangat positif maka respon siswa dapat disebut baik dam apabila $<75 \%$ dari seluruh butir pernyataan yang dikategorikan positif atau sangat positif maka respon siswa dapat disebut tidak baik. 


\section{HASIL PENELITIAN DAN PEMBAHASAN}

\section{Hasil Penelitian}

Berdasarkan validasi yang telah dilakukan oleh beberapa validator ahli pendidikan dan telah direvisi oleh peneliti maka instrumen penelitian serta media Komik Digital ini dapat dikatakan layak untuk digunakan penelitian. Komik Digital dalam penelitian ini termasuk dalam jenis komik pendidikan yang dikemas secara ringkas berbentuk buku digital dimana mengandung unsur informatif untuk menyampaikan informasi kepada siswa dimana komik ini menceritakan permasalahan nyata di lingkungan sekolah dengan percakapan sehari-hari antar tokoh yaitu Renata Keishsya Putri sebagai karakter utama, Farah Biancara dan Maya Cayyara Zai sebagai karakter pendamping. Berikut adalah ilustasi media Komik Digital pada materi SPLDV, dapat dilihat pada Gambar 12.

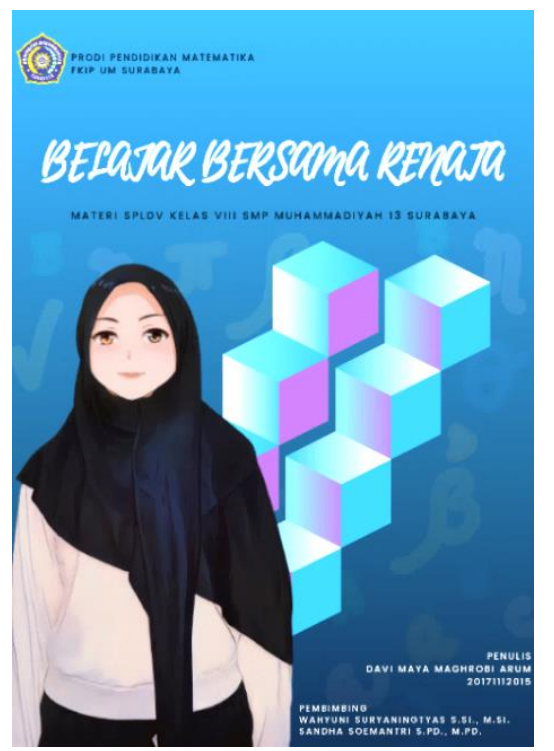

Gambar 1. Cover Media Komik Digital

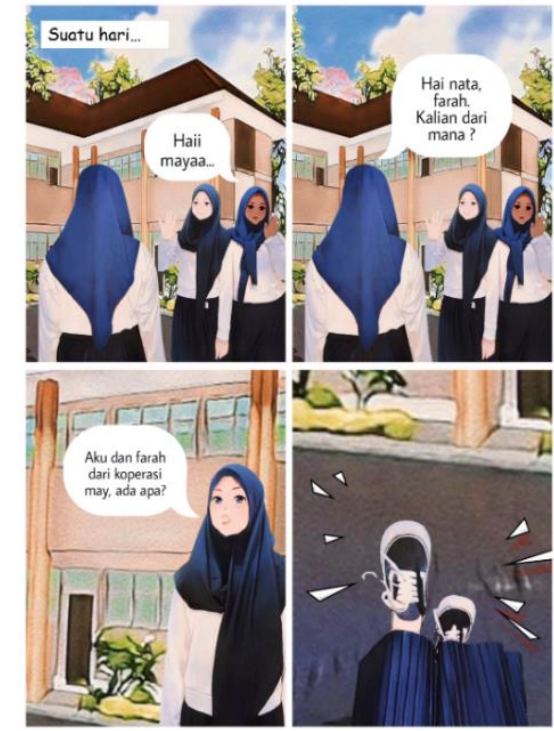

Gambar 2. Cerita dalam Media Komik Digital

Dari hasil penelitian yang dilakukan diperoleh bahwa hasil pengamatan terhadap keterlaksanaan guru dalam mengelola pembelajaran dapat dilihat pada Tabel 4.

Tabel 4. Hasil Observasi Keterlaksanaan Pembelajaran Guru

\begin{tabular}{|c|l|c|}
\hline \multicolumn{1}{|c|}{ Tahap } & \multicolumn{1}{|c|}{ Aspek yang Diamati } & Jumlah \\
\hline PENDAHULUAN & Orientasi, Apersepsi, Motivasi. & 9 \\
\hline KEGIATAN INTI & Fase 1 : Orientasi siswa pada masalah & 6 \\
\cline { 2 - 3 } & Fase 2 : Mengorganisasikan siswa & 5 \\
\cline { 2 - 3 } & $\begin{array}{l}\text { Fase 3 : Membimbing penyelidikan individu } \\
\text { atau kelompok }\end{array}$ & 6 \\
\hline
\end{tabular}




\begin{tabular}{|c|l|c|}
\hline & $\begin{array}{l}\text { Fase 4 : Mengembangkan dan menyajkan } \\
\text { hasil karya }\end{array}$ & 4 \\
\cline { 2 - 3 } & $\begin{array}{l}\text { Fase 5 : Menganalisa dan mengevaluasi } \\
\text { proses pemecahan permasalahan }\end{array}$ & 6 \\
\hline & \multicolumn{1}{|c|}{ PENUTUP } & 4 \\
\hline Rata-rata & & 0,952 \\
\hline Persentase & & $95 \%$ \\
\hline
\end{tabular}

Berdasarkan Tabel 4, hasil perolehan persentase keterlaksanaan guru mengelola pembelajaran dari pertemuan pertama dan pertemuan kedua yaitu sebesar 95\%. maka dapat disimpulkan bahwa penilaian terhadap keterlaksanaan guru dalam mengelola pembelajaran secara keseluruhan dalam kategori sangat baik. Data hasil observasi aktivitas siswa ini dapat dilihat pada Tabel 5 .

Tabel 5. Hasil Observasi Aktivitas Siswa

\begin{tabular}{|c|c|c|}
\hline No & Aktivitas yang Diamati & Rata-rata \\
\hline 1 & A & 3,85 \\
\hline 2 & B & 3,60 \\
\hline 3 & C & 3,52 \\
\hline 4 & D & 3,53 \\
\hline 5 & E & 4,00 \\
\hline 6 & F & 3,66 \\
\hline Rata-rata & & 3,70 \\
\hline SAS & \multicolumn{2}{|}{} \\
\hline
\end{tabular}

Keterangan :

A : Memperhatikan penjelasan materi/pertanyaan yang disampaikan oleh guru maupun teman

B : Merespon penjelasan/ pertanyaan yang disampaikan oleh guru maupun teman. Misal mengajukan pertanyaan atau menjawab pertanyaan

C: Menunjukan pemahaman terhadap masalah yang diberikan oleh guru. Misal mengerjakan contoh permasalahan yang diberikan dan berani berpendapat

D : Mempresentasikan hasil kerja contoh permasalahan yang diberikan

E : Mengerjakan tugas yang diberikan dengan batas waktu yang ditentukan

F: Melakukan kegiatan yang relevan dengan pembelajaran. Misal memperhatikan teman presentasi, menyimpulkan materi yang telah dipelajari

Berdasarkan Tabel 5 didapat hasil perolehan rata-rata skor aktivitas siswa dari pertemuan pertama hingga pertemuan kedua yaitu sebesar 3,70. Maka dapat disimpulkan bahwa data penilaian terhadap aktivitas siswa secara keseluruhan termasuk dalam kategori sangat aktif.

Berdasarkan perhitungan hasil tes pada kelas VIII-B SMP Muhammadiyah 13 Surabaya setelah dilaksanakan penerapan pembelajaran matematika 
menggunakan media Komik Digital dengan model pembelajaran Problem Based Learning (PBL) pada materi SPLDV diperoleh data pada Tabel 6.

Tabel 6. Data Hasil Belajar

\begin{tabular}{|c|c|c|}
\hline Keterangan & Jumlah Siswa & Persentase \\
\hline Siswa Tuntas & 30 & $97 \%$ \\
\hline Siswa Tidak Tuntas & 1 & $3 \%$ \\
\hline
\end{tabular}

Berdasarkan Tabel 6 diketahui hasil belajar siswa kelas VIII-B setelah diterapkan pembelajaran matematika menggunakan Komik Digital pada materi SPLDV sub bab eliminasi dan substitusi mendapatkan persentase sebesar $97 \%$ dinyatakan tuntas dengan sebanyak 30 siswa. Selanjutnya sebesar 3\% dinyatakan tidak tuntas dengan sebanyak 1 siswa sehingga dapat disimpulkan bahwa ketuntasan hasil belajar kelas secara klasikal telah tercapai.

Data respon siswa dalam penelitian ini adalah tanggapan siswa terhadap pembelajaran matematika menggunakan Komik Digital sebagai media pembelajaran daring pada materi SPLDV dengan sub bab eliminasi dan substitusi. Berikut pada Tabel 7 adalah hasil angket respon yang telah diisi oleh siswa:

Tabel 7. Data Hasil Respon Siswa

\begin{tabular}{|c|c|c|}
\hline No & Aktivitas yang Dinilai & NRS\% \\
\hline 1 & AA & $95 \%$ \\
\hline 2 & AB & $95 \%$ \\
\hline 3 & AC & $92 \%$ \\
\hline 4 & AD & $94 \%$ \\
\hline 5 & AE & $91 \%$ \\
\hline 6 & AF & $88 \%$ \\
\hline 7 & AG & $92 \%$ \\
\hline 8 & AH & $95 \%$ \\
\hline 9 & Al & $95 \%$ \\
\hline 10 & AJ & $95 \%$ \\
\hline 11 & AK & $95 \%$ \\
\hline 12 & AL & $92 \%$ \\
\hline 13 & AM & $82 \%$ \\
\hline 14 & AN & $86 \%$ \\
\hline 15 & AO & $89 \%$ \\
\hline
\end{tabular}

Keterangan:

AA : $\quad$ Banyak materi pelajaran yang saya serap secara mandiri dengan menggunakan media Komik Digital berbasis PBL pada materi SPLDV

$A B$ : $\quad$ Belajar Matematika menggunakan media Komik Digital berbasis PBL mendorong saya untuk menemukan ide-ide baru

AC: Media Komik Digital berbasis PBL dapat meningkatkan motivasi belajar dalam pembelajaran matematika pada materi SPLDV 
AD : $\quad$ Belajar matematika menggunakan media Komik Digital berbasis PBL membuat materi mudah diingat

AE : $\quad$ Media Komik Digital berbasis PBL membuat pelajaran matematika lebih menarik untuk dipelajari

AF : Pembelajaran matematika menggunakan media Komik Digital berbasis PBL ini perlu diterapkan dalam pembelajaran matematika dengan materi lain

AG : $\quad$ Materi SPLDV menjadi lebih jelas menggunakan media Komik Digital berbasis PBL

$\mathrm{AH}$ : $\quad$ Cara penyelesaian pada materi SPLDV dalam media komik digital tertulis dengan jelas sehingga menjadi mudah saya pahami

Al: $\quad$ Media Komik Digital ini memiliki desain yang menarik, dan cocok digunakan dalam proses pembelajaran

AJ : $\quad$ Media Komik Digital berbasis PBL ini layak digunakan dalam materi SPLDV

Berdasarkan Tabel 7 dapat dilihat bahwa seluruh jawaban angket respon siswa dari 31 siswa terhadap pembelajaran matematika menggunakan media Komik Digital pada materi SPLDV khususnya sub bab eliminasi dan substitusi termasuk dalam kategori sangat positif.

Data hasil pengamatan keterlaksanaan guru dalam mengelola pembelajaran dianalisis dengan menghitung nilai rata-rata keseluruhan selama dua kali pertemuan. Berdasarkan Tabel 4 terlihat bahwa hasil perolehan rata-rata keterlaksanaan guru mengelola pembelajaran menggunakan media Komik Digital dengan model pembelajaran Problem Based Learning (PBL) pada materi SPLDV dari pertemuan pertama hingga pertemuan kedua secara keseluruhan yaitu sebesar $95 \%$ dan dalam kategori sangat baik sesuai dengan ketentuan Tabel 1.

Aktivitas siswa terhadap pembelajaran dianalisis dengan mendeskripsikan hasil skor tiap aktivitas siswa selama kegiatan pembelajaran berlangsung. Berdasarkan Tabel 5 terlihat bahwa hasil perolehan rata-rata skor aktivitas siswa selama proses pembelajaran yang telah diamati oleh observer pada pertemuan pertama hingga pertemuan kedua secara keseluruhan yaitu 3,70 dan termasuk dalam kategori sangat aktif

Ketuntasan hasil belajar siswa ini didasarkan pada standar ketuntasan SMP Muhammadiyah 13 Surabaya tahun ajaran 2020/2021 yaitu seorang siswa dapat dikatakan tuntas belajar secara individu jika mendapatkan skor sebesar $\geq$ 75 dari skor maksimum yaitu 100, dan suatu kelas dapat dikatakan tuntas belajar secara klasikal jika 75\% siswa mencapai ketuntasan belajar individu. Berdasarkan Tabel 6 terlihat bahwa perolehan hasil belajar siswa kelas VIII-B SMP Muhammadiyah 13 setelah diterapkan pembelajaran matematika menggunakan media Komik Digital pada materi SPLDV sub bab eliminasi dan substitusi mendapatkan persentase dengan kriteria tuntas sebesar $97 \%$ dengan sebanyak 30 siswa. Selanjutnya persentase dengan kriteria tidak tuntas sebesar 3\% dengan sebanyak 1 siswa. Ketuntasan klasikal pada kelas VIII-B SMP Muhammadiyah 13 Surabaya terlah tercapai dengan persentase sebesar $97 \%$ sehingga pembelajaran dapat dikatakan efektif. Maka dapat disimpulkan ada perbedaan signifikan hasil belajar siswa antara sebelum dan sesudah pembelajaran dengan media pembelajaran daring Komik Digital pada materi SPLDV dimana sebelum dilakukan 
pembelajaran dengan menggunakan Komik Digital hasil belajar siswa hanya mencapai sebesar $28,57 \%$.

Data hasil angket respon siswa pada kelas VIII-B SMP Muhammadiyah 13 berdasarkan Tabel 7 terlihat bahwa perolehan skor respon siswa dari 31 siswa terhadap pembelajaran matematika menggunakan media Komik Digital pada materi SPLDV termasuk dalam kategori sangat positif dengan persentase sebesar $\geq 75 \%$ untuk masing-masing pernyataan. Berdasarkan perhitungan keseluruhan, banyaknya respon siswa dalam kategori sangat positif mencapai $75 \%$. Sesuai dengan Tabel 3 yaitu jika $\geq 50 \%$ dari seluruh butir pernyataan termasuk kategori positif sedangkan $\geq 75 \%$ termasuk kategori sangat positif. Sehingga dapat disimpulkan bahwa respon siswa terhadap pembelajaran matematika menggunakan Komik Digital sebagai media pembelajaran daring termasuk kategori efektif.

\section{Pembahasan}

Berdasarkan hasil penelitian terdahulu yang relevan terhadap media pembelajaran komik digital yang pernah dilakukan oleh Kartika Sari (2019) dengan judul "Pengembangan Komik Digital Berbasis Pendidikan Karakter Pada Materi Pokok Bahasan Bangun Datar Untuk Kelas IV SD/MI" di mana dalam media yang digunakan tersebut hanya memiliki unsur gambar berupa foto atau gambar dan dialog, sedangkan media pembelajaran komik digital yang dibuat oleh peneliti adalah media pembelajaran sederhana yang disajikan dalam media elektronik, namun memiliki unsur yang lengkap yaitu unsur gambar, suara, dan video agar siswa tertarik dalam menggunakan sebagai media pembelajaran. Penggunaan media komik digital ini dapat akses melalui website menggunakan link yang telah disiapkan peneliti dimana dalam media sudah berisi materi, kuis pembelajaran, beserta video pembelajaran sesuai materi yang diberikan secara gratis kepada siswa. Desain media komik digital juga dibuat dengan menarik agar siswa tidak merasa jenuh dan bosan dengan pembelajaran yang berlangsung.

Media pembelajaran komik digital ini dibuat dengan sederhana yang disajikan dalam media elektronik, namun memiliki unsur yang lengkap yaitu unsur gambar, suara, dan video agar siswa tertarik dalam menggunakan sebagai media pembelajaran. Penggunaan media komik digital ini dapat akses menggunakan link yang telah disiapkan peneliti dimana dalam media sudah berisi materi, kuis pembelajaran, beserta video pembelajaran sesuai materi yang diberikan secara gratis kepada siswa. Desain media komik digital juga dibuat dengan semenarik mungkin agar siswa tidak merasa jenuh dan bosan dengan pembelajaran yang berlangsung.

Data hasil pengamatan keterlaksanaan guru dalam mengelola pembelajaran dianalisis dengan menghitung nilai rata-rata skor gabungan keseluruhan selama dua kali pertemuan. Selanjutnya menginterpretasikan rata-rata skor dengan kriteria tiap aspek yang digunakan adalah "terlaksana" dengan skor 1, dan "tidak terlaksana" dengan skor 0 untuk tiap item pernyataan. Berdasarkan Tabel 4 terlihat bahwa hasil perolehan rata-rata persentasi keterlaksanaan guru mengelola pembelajaran dengan menggunakan media Komik Digital dengan 
model pembelajaran Problem Based Learning (PBL) pada materi SPLDV dari pertemuan pertama hingga pertemuan kedua secara keseluruhan yaitu sebesar 95\% dan dalam kategori sangat baik sesuai dengan ketentuan Tabel 1 dengan demikian RPP dapat dikatakan praktis.

Dari hasil observasi diperoleh data aktivitas siswa selama proses pembelajaran yang kemudian dianalisis dengan menghitung nilai rata-rata skor gabungan pada setiap pertemuuan dengan rubrik penilaian skor 1 untuk "'tidak sesuai", skor 2 untuk "kurang sesuai", skor 3 untuk "baik", dan skor 4 untuk "sangat baik", selanjutnya menghitung nilia rata-rata skor total semua pernyataan dan menginterpretasikan nilai rata-rata aktivitas siswa pada tiap item pernyataan serta menentukan kategori penilaian sesuai Tabel 2. Setelah mendapatkan skor keseluruhan kemudia mendeskripsikan hasil skor tiap aktivitas siswa selama kegiatan pembelajaran berlangsung untuk setiap pertemuan. Berdasarkan Tabel 5 terlihat bahwa hasil perolehan rata-rata skor aktivitas siswa selama proses pembelajaran yang telah diamati oleh observer pada pertemuan pertama hingga pertemuan kedua secara keseluruhan yaitu 3,70 dan termasuk dalam kategori sangat aktif.

Data hasil belajar siswa diperoleh dari hasil tes yang diberikan kepada siswa pada akhir pertemuan yaitu tes akhir/posstest. Tes dilakukan untuk mengetahui tingkat kemampuan atau sejauh mana ketuntasan belajar siswa dalam memahami, menguasai materi serta menyelesaikan permasalahan terkait materi pembelajaran. Ketuntasan hasil belajar siswa ini didasarkan pada standar ketuntasan SMP Muhammadiyah 13 Surabaya tahun ajaran 2020/2021 yaitu seorang siswa dapat dikatakan tuntas belajar secara individu jika mendapatkan skor sebesar $\geq 75$ dari skor maksimum yaitu 100, dan suatu kelas dapat dikatakan tuntas belajar secara klasikal jika $75 \%$ siswa mencapai ketuntasan belajar individu. Berdasarkan Tabel 6 terlihat bahwa perolehan hasil belajar siswa kelas VIII-B SMP Muhammadiyah 13 setelah diterapkan pembelajaran matematika menggunakan media Komik Digital pada materi SPLDV sub bab eliminasi dan substitusi mendapatkan persentase dengan kriteria tuntas sebesar $97 \%$ dengan sebanyak 30 siswa. Selanjutnya persentase dengan kriteria tidak tuntas sebesar 3\% dengan sebanyak 1 siswa. Ketuntasan klasikal pada kelas VIII-B SMP Muhammadiyah 13 Surabaya terlah tercapai dengan persentase sebesar $97 \%$ sehingga pembelajaran dapat dikatakan efektif. Maka dapat disimpulkan ada perbedaan signifikan hasil belajar siswa antara sebelum dan sesudah pembelajaran dengan media pembelajaran daring Komik Digital pada materi SPLDV dimana sebelum dilakukan pembelajaran dengan menggunakan Komik Digital hasil belajar siswa hanya mencapai sebesar $28,57 \%$.

Data hasil angket respon siswa digunakan untuk mengetahui respon siswa kelas VIII-B SMP Muhammadiyah 13 Surabaya dalam proses pembelajaran menggunakan media komik digital pada materi SPLDV. Pembelajaran dapat dikatakan efektif apabila perolehan skor respon siswa minimal $75 \%$ dengan kategori positif dengan ketentuan pilihan yaitu SS untuk "sangat setuju", S untuk "setuju", TS untuk "tidak setuju", dan STS untuk "sangat tidak setuju" kemudian menghitung jumlah respon siswa untuk setiap butir pernyataan yang dipilih, dan 
menentukkan presentase nilai respon siswa untuk tiap pernyataan sesuai dengan Tabel 3 Berdasarkan Tabel 7 terlihat bahwa perolehan skor respon siswa dari 31 siswa terhadap pembelajaran matematika menggunakan media Komik Digital pada materi SPLDV termasuk dalam kategori sangat positif dengan persentase sebesar $\geq 75 \%$ untuk masing-masing pernyataan. Berdasarkan perhitungan keseluruhan, banyaknya respon siswa dalam kategori sangat positif mencapai 75\%. Sesuai dengan Tabel 3 yaitu jika $\geq 50 \%$ dari seluruh butir pernyataan termasuk kategori positif sedangkan $\geq 75 \%$ termasuk kategori sangat positif. Sehingga dapat disimpulkan bahwa respon siswa terhadap pembelajaran matematika menggunakan Komik Digital sebagai media pembelajaran daring termasuk kategori baik.

\section{SIMPULAN}

Data hasil observasi Keterlaksanaan guru dalam mengelola pembelajaran matematika menggunakan Komik Digital sebagai media pembelajaran daring pada materi SPLDV pada sub bab eliminasi dan substitusi memperoleh nilai ratarata 0,952 dengan persentase sebesar $95 \%$ dan dalam kategori sangat baik. Data hasil observasi aktivitas siswa selama mengikuti pembelajaran matematika menggunakan Komik Digital sebagai media pembelajaran daring pada materi SPLDV pada sub bab eliminasi dan substitusi memperoleh rata-rata secara keseluruhan sebesar 3,70 dan termasuk kategori sangat aktif. Data hasil belajar siswa kelas VIII-B SMP Muhammadiyah 13 Surabaya untuk mengetahui ketuntasan belajar siswa setelah mengikuti pembelajaran matematika menggunakan Komik Digital sebagai media pembelajaran daring pada materi SPLDV dikatakan tuntas karena persentase ketuntasan klasikal mencapai $97 \%$. Data hasil respon siswa dikatakan baik karena secara keseluruhan butir pernyataan yang telah dipilih siswa termasuk dalam kategori sangat positif. Karena dari perolehan keterlaksanaan guru dalam mengelola pembelajaran, aktivitas siswa, respon siswa dalam kategori baik serta ketuntasan hasil belajar siswa dari sebelum dan sesudah pembelajaran terdapat perbedaan signifikan maka pembelajaran matematika menggunakan Komik Digital sebagai media pembelajaran daring pada materi SPLDV dapat disimpulkan termasuk dalam efektif.

\section{UCAPAN TERIMA KASIH}

Penulis mengucapkan terimakasih kepada Kepala sekolah, guru, staf dan siswa di SMP Muhammadiyah 13 Surabaya, Universitas Muhammadiyah Surabaya, Program Studi Pendidikan Matematika, dan semua pihak yang telah memberikan kritik dan saran yang sangat berguna dalam penulisan artikel ini

\section{DAFTAR PUSTAKA}

Affidah, A. M. (2017). Efektivitas Penerapan Pembelajaran Conceptual Understanding Procedures (CUPs) untuk Melatih Kemampuan Koneksi Matematika Siswa. Digital Library of UIN Sunan Ampel, 43-47. 
Andesta, L. (2017). Pengaruh Model Pembelajaran Problem Based Learning (PBL) Terhadap Hasil Belajar Matematika Peserta Didik Di Kelas IV MIN 11 Bandar Lampung. Repository Radenintan.

Astraman, K. A., Dibia, I. K., \& Mahadewi, L. P. P. (2017). Pengaruh Model Problem Based Learning (PBL) Bermediakan Gambar Terhadap Hasil Belajar IPA Siswa Kelas V. Mimbar PGSD Universitas Pendidikan Ganesha, 5(2), 1-10.

Kartika Sari, C. (2019). Pengembangan Komik Digital Berbasis Pendidikan Karakter Pada Materi Pokok Bahasan Bangun Datar Untuk Kelas IV SD/MI.

Kemenkeu. (2005). Undang-undang republik indonesia nomor 14 tahun 2005. https://jdih.kemenkeu.go.id/fulltext/2005/14TAHUN2005UU.htm

Kurniati, D., Rahimah, D., \& Rusdi, R. (2017). Efektivitas Media Komik Pada Materi Sifat-Sifat Bangun Ruang Untuk Siswa Kelas V Sd Negeri 6I Kota Bengkulu. Jurnal Penelitian Pembelajaran Matematika Sekolah (JP2MS), 1(1), 14-19. https://doi.org/10.33369/jp2ms.1.1.14-19

Laela, K. (2013). Penerapan Metode Guide Note Taking dalam Pembelajaran Matematika dengan Pokok Bahasan Keliling Dan Luas Lingkaran Pada Peserta Didik Kelas VIII SMP Muhammadiyah 4 Giri. Muhammadiyah University Of Gresik Repository, 30-31.

Laksana, M. N. (2019). Implementasi Sistem Manajemen Keselamatan dan Kesehatan Kerja di Bengkel Program Keahlian Teknlogi Konstruksi dan Properti SMK N 1 Magelang.

Marsigit, \& Roh, A. K. (2015). Pengembangan Perangkat Pembelajaran Dengan Pendekatan Problem Solving Untuk Meningkatkan Kemampuan Pemahaman Konsep Pada Materi Bangun Ruang Sisi Datar Siswa SMP Kelas VIII. Lumbung Pustaka Universitas Negeri Yogyakarta, 50.

Permana sidik, I. (2013). Efektivitas Media Komik Digital Terhadap Peningkatan Hasil Belajar Siswa Pada Mata Pelajaran Sejarah. Repository UPI (The Education University)

Rahmah, N. (2013). Hakikat Matematika. al-Khwarizmi, 4. Repository UPI (The Education University)

Siregar, N. R. (2017). Persepsi Siswa Pada Pelajaran Matematika : Studi Pendahuluan pada Siswa yang Menyenangi Game. Prosiding Temu IImiah Nasional X Ikatan Psikologi Perkembangan Indonesia (hal. 227). Semarang: Ikatan Psikologi Perkembangan.

Sugiyono. (2013). Metode Penelitian Kuantitatif, Kualitatif, dan R\&D. Bandung: ALFABETA 